\title{
Quartz-Bearing C-O-H Fluid Inclusions Diamond: Retracing the pressure- temperature Path in the Mantle using Calibrated High Temperature IR Spectroscopy
}

Emma L. Tomlinson ${ }^{1}$, Paul F. McMillan ${ }^{2,3}$, Ming Zhang ${ }^{4}$, Adrian P. Jones ${ }^{5}$, Simon A.T. Redfern ${ }^{4}$

${ }^{1}$ Department of Geology, Royal Holloway University of London, Egham Hill, Egham, Surrey, TW20 0EX, U.K.

${ }^{2}$ Department of Chemistry and Materials Chemistry Centre, University College London, 20 Gordon Street, London, WC1H OAJ, U.K.

${ }^{3}$ Davy-Faraday Research Laboratory, Royal Institution, 21 Albemarle Street, London, W1S 4BX, U.K.

${ }^{4}$ Department of Earth Sciences, University of Cambridge, Downing Street, Cambridge, CB2 3EQ, U.K.

${ }^{5}$ Department of Earth Sciences, University College London, Gower Street, London, WC1E 6BT, U.K. 


\begin{abstract}
Infrared spectra of $\mathrm{C}-\mathrm{O}-\mathrm{H}$ micro-inclusions were collected from a microinclusion bearing diamond during step-heating and freezing experiments to examine fluid speciation as a function of pressure and temperature. The inclusions contain $\mathrm{H}_{2} \mathrm{O}, \mathrm{CO}_{2}$, carbonate, apatite, quartz and mica, which together represent the oxidising remnant mantle fluid composition after diamond crystallisation. The internal pressure of the inclusions, measured from calibrated shifts of the quartz peaks, increases from $1.3 \mathrm{GPa}$ at ambient temperature, to approximately $4-5 \mathrm{GPa}$ at $737^{\circ} \mathrm{C}$, close to the conditions of crystallisation of the host diamond in the mantle.
\end{abstract}

\title{
1. INTRODUCTION
}

Determining the nature and thermodynamic properties of mantle fluids is necessary to understand how volatiles influence mineral equilibria at depth, including diamond formation. The best source of information on mantle fluids is from samples contained as inclusions within minerals that have been formed at and subsequently erupted from great depth, especially diamonds. The deepest and most pristine samples of mantle fluids to date occur within micrometer sized inclusions in diamonds with cuboid morphology and in the fibrous coats of coated diamonds (Chrenko et al., 1967; Guthrie et al., 1991; Navon et al., 1988), in which fluid micro-inclusions are trapped along the lateral surfaces of the diamond fibres during diamond growth (Kamiya and Lang, 1965). Both the fibrous morphology and the presence of the fluid inclusions are consistent with rapid diamond growth occurring from a fluid phase. Any fluid and mineral species trapped within the inclusions thus give an indication of the composition and properties of the fluid that was present in the mantle during precipitation of the host diamond, before closure of the inclusions and subsequent eruption of the diamond-bearing kimberlite magma.

The minimum pressure-temperature conditions for formation of diamond are generally constrained by the intersection of the graphite-diamond equilibrium line (Berman and Simon, 1955; Bundy et al., 1961; Kennedy and Kennedy, 1976) with an appropriate mantle geotherm. For geotherms ranging between $37-40 \mathrm{mWm}^{-2}$, this occurs at $800-$ $950^{\circ} \mathrm{C}$ and 3.6-4.0 GPa. Taking these considerations into account, the micro-inclusions in fibrous and cuboid diamonds are expected to represent samples of mantle fluids from $\geq 100 \mathrm{~km}$ depth. Such micro-inclusions in diamond can retain very high residual internal pressures at room temperature, ranging up to 0.6-0.8 GPa (Kagi et al., 2006) and 1.52.1 GPa (Navon, 1991).

In the present work, we studied the fluid and mineral species present within inclusions contained in a type laA micro-inclusion bearing diamond sample from the Democratic Republic of Congo (DRC), using Fourier transform infrared (FTIR) spectroscopy. The FTIR spectra of the inclusions were obtained at low-temperature $\left(-253\right.$ to $\left.25^{\circ} \mathrm{C}\right)$ and high-temperature $\left(25\right.$ to $\left.737^{\circ} \mathrm{C}\right)$ conditions. The inclusions represent a closed system with a nearly constant volume and pressures exerted on phases within the inclusions were approximately hydrostatic. The internal pressures were determined using the IRactive modes of $\mathrm{SiO}_{2}$ quartz that was observed to be present within the inclusions as a pressure calibrant.

\section{MATERIALS AND METHODS}

\subsection{Sample Description}


The sample is a $4 \mathrm{~mm}$ diameter alluvial micro-inclusion bearing diamond obtained from Diamant Board, Belgium (Judith Milledge, pers comm.), but likely originating from the Mbuji Mayi kimberlite (Democratic Republic of Congo). Crystalline inclusions in microinclusion bearing diamonds have shown they may grow in a peridotitic and eclogitic host rocks, like normal diamonds (Tomlinson et al., 2006). The diamond is yellow in colour and has an octahedral external morphology. The sample consists of a less opaque (inclusion-poor) inner zone and an opaque (inclusion-rich) outer zone (Fig. 1). The inclusions are sub-microscopic (up to $1 \mu \mathrm{m}$ in diameter) and are similar to those in the fibrous coats of coated diamonds. Transmission Electron Microscopy indicates that inclusions in such diamonds are generally $\ll<0.5 \mu \mathrm{m}$ in diameter (Guthrie et al., 1991), and that mineral phases occupy only a fraction of the inclusion volume, the rest being fluid (Guthrie et al., 1991; Klein-BenDavid et al., 2006). This indicates that the solid phases precipitated from the fluid after trapping, rather than being included samples of the host rock. Experimental diamond growth in the system carbonate- $\mathrm{H}_{2} \mathrm{O}-\mathrm{CO}_{2}$ suggests that a diamond of this size should take tens to hundreds of thousands of years to form (Pal'yanov et al., 2002). However, the uptake of large numbers of fluid inclusions is consistent with significantly more rapid growth. The sample was laser cut to a thickness of $0.4 \mathrm{~mm}$ and polished on both sides; the final sample weighed $0.08 \mathrm{ct}$.

\subsection{Variable temperature FTIR Analysis}

Variable-temperature FTIR experiments were carried out between -253 to $737^{\circ} \mathrm{C}$ over the range $4400-400 \mathrm{~cm}^{-1}$ with a Bruker IFS113v FTIR instrument, using a SiC Globar light source, a Ge-coated $\mathrm{KBr}$ beam splitter and an MCT detector. The beam size was $\sim 10 \mathrm{~mm}$ and the sample thickness was $0.4 \mathrm{~mm}$, so the resultant spectra represent a statistical average over many thousands of inclusions. Measurements were carried out in absorption at a spectral resolution of $2 \mathrm{~cm}^{-1}$ with one spectrum being the average obtained from 512 scans.

Low-temperature experiments were conducted under vacuum $\left(10^{-3} \mathrm{~Pa}\right)$ using a Leybold He-cryostat, the vacuum chamber was equipped with KRS5 windows. Samples were mounted on a high-thermal-conductivity Cu-plate with a central gap, indium foil was used to improve the contact between the sample and holder. Temperature was measured at 40 degree intervals using a Si-diode sensor (LakeShore, DT-470-DI-13). Hightemperature experiments were conducted under vacuum using a cylindrical Pt-wound resistance furnace. The sample was masked with $\mathrm{Pt}$ foil. The heating rate was 15 degrees per minute and temperature was measured using a $\mathrm{NiCr} / \mathrm{NiAl}$ thermocouple at the sample surface. This thermocouple is calibrated by using the a- $\beta$ transition temperatures of quartz and cristobalite. Spectra were collected at 25 degree intervals from room temperature to $200^{\circ} \mathrm{C}$ and then at 50 degree intervals up to $737^{\circ} \mathrm{C}$. The instrumental precision is \pm 5 at $<375^{\circ} \mathrm{C}$ and \pm 10 at $>375^{\circ} \mathrm{C}$.

\section{RESULTS}

The main part of the sample corresponded to a type laA diamond showing characteristic IR absorption peaks due to substitutional nitrogen in the region $1350-1100$ and $480 \mathrm{~cm}^{-1}$, and 2nd- and 3rd-order diamond vibrational modes in the $2700-1600 \mathrm{~cm}^{-1}$ regions (Fig. 2). Additional weak peaks were observed throughout the $400-3000 \mathrm{~cm}^{-1}$ range, due to a multitude of $\mathrm{C}-\mathrm{O}-\mathrm{H}$ inclusions along with associated minerals present within the inclusions.

\subsection{Mineral Phases}


The presence of crystalline quartz (alpha polymorph) within the inclusions detected by FTIR spectroscopy is discussed in section 3.3. The IR spectra also reveal the presence of other mineral phases (Fig. 2), that likely include apatite $\left(\mathrm{Ca}_{3}\left(\mathrm{PO}_{4}\right)_{2}(\mathrm{OH}, \mathrm{F})\right)$, carbonate minerals $\left((\mathrm{Ca}, \mathrm{Mg}) \mathrm{CO}_{3}\right)$ and $(\mathrm{OH}, \mathrm{F})$-phlogopite. Apatite is identified by its characteristic peaks at 579 and $606 \mathrm{~cm}^{-1}$ (Ross, 1974); however, the dominant $\mathrm{P}-\mathrm{O}$ stretching mode is hidden under the strong silicate peak at $1002 \mathrm{~cm}^{-1}$, but the $\mathrm{Ca}_{3}\left(\mathrm{PO}_{4}\right)_{2}(\mathrm{OH}, \mathrm{F})$ phase could give rise to the shoulder at $1061 \mathrm{~cm}^{-1}$. Apatite has been identified in previous studies of micro-inclusion bearing diamonds by X-ray diffraction and TEM techniques (Guthrie et al., 1991; Klein-BenDavid et al., 2006; Lang and Walmsley, 1983). These phases are consistent with the electron microprobe data which indicate that the inclusions are enriched in $\mathrm{SiO}_{2}, \mathrm{CaO}, \mathrm{MgO}$ and $\mathrm{K}_{2} \mathrm{O}$ (Tomlinson, 2005); the inclusions do not contain a significant component of $\mathrm{KCl}$ brine.

The $v_{2}$ bending and $v_{3}$ stretching modes of planar $\mathrm{CO}_{3}^{-2}$ ions of carbonate minerals occur at $876 \mathrm{~cm}^{-1}$ and $\sim 1440 \mathrm{~cm}^{-1}$ respectively; the $v_{3}$ mode is broad and asymmetric, perhaps suggesting the presence of more than one carbonate phase. At low temperature, the $v_{3}$ mode becomes resolved into a band at $1430 \mathrm{~cm}^{-1}$ with a shoulder at $1461 \mathrm{~cm}^{-1}$, suggesting that the inclusions might contain a mixture of magnesite and either dolomite or calcite (White, 1974). Two small peaks at $748 \mathrm{~cm}^{-1}$ and $728 \mathrm{~cm}^{-1}$ may then be attributed to the $v_{4}$ bending mode of the $\mathrm{CO}_{3}{ }^{2-}$ ion in dolomite and magnesite respectively (White, 1974). Previous X-ray and TEM studies of phases contained in micro-inclusion bearing diamond inclusions have identified assemblages of dolomite + calcite (Walmsley and Lang, 1992a), and dolomite + magnesite (Guthrie et al., 1991; Klein-BenDavid et al., 2006).

The IR peaks at 1001,834 and $660-690 \mathrm{~cm}^{-1}$ are more difficult to assign. The strong peak at $1002 \mathrm{~cm}^{-1}$ is probably due to $\mathrm{Si}-\mathrm{O}$ stretching, possibly in mica whose peaks occur at 994-1019 (phengite) and $1010 \mathrm{~cm}^{-1}$ (phlogopite) (Farmer, 1974). The broad 660-690 band may due to an unresolved combination of Si-O, Mg-O and Al-O vibrations. If the silicate present is mica, then the $834 \mathrm{~cm}^{-1}$ peak could be due to Al-O stretching vibrations (Beran, 2002). Initially countering this interpretation is that no corresponding $\mathrm{O}-\mathrm{H}$ features are observed at $\sim 3700 \mathrm{~cm}^{-1}$. The non-observance of mica $\mathrm{O}-\mathrm{H}$ features could be due to the large amount of $\mathrm{H}_{2} \mathrm{O}$ component (fluid or ice- $\mathrm{VI}$ ) in the inclusions, which may mask the $\mathrm{O}-\mathrm{H}$ features. Biotite-phlogopite and phengite-celadonite have previously been identified in micro-inclusion bearing diamond inclusions using $\mathrm{x}$-ray and TEM techniques (Klein-BenDavid et al., 2006; Walmsley and Lang, 1992b). IR peaks at 1020, 1000 (shoulder), 1072, 1095 (shoulder), 832 and $460 \mathrm{~cm}^{-1}$ in micro-inclusion bearing diamond spectra have previously been assigned to mica (Klein-BenDavid et al., 2006).

\subsection{C-O-H Species Present Within the Inclusions}

The FTIR spectrum of the diamond sample indicates the presence of $\mathrm{C}-\mathrm{O}-\mathrm{H}$ species. At room temperature, the IR spectra contain a broad intense band extending between 2800-3800 $\mathrm{cm}^{-1}$, along with a peak at $1657 \mathrm{~cm}^{-1}$ (Fig. 2), that indicate the $\mathrm{O}-\mathrm{H}$ stretching and $\mathrm{HOH}$ bending vibrations of liquid $\mathrm{H}_{2} \mathrm{O}$.

Under such high-pressure conditions, any free $\mathrm{H}_{2} \mathrm{O}$ phase contained within the inclusions should be present as the solid ice VI polymorph (Bridgman, 1935; MincevaSukarova et al., 1984; Datchi et al., 2000; Fei et al., 1993). This high pressure form of 
$\mathrm{H}_{2} \mathrm{O}$ ice was not observed during early studies of diamond $\mathrm{C}-\mathrm{O}-\mathrm{H}$ inclusions (Navon, 1991 ), even when the samples were cooled to $-196^{\circ} \mathrm{C}$. However, its absence could be attributed to various experimental factors, including the high surface-to-volume ratio and/or the high solute content of the inclusions (Navon, 1991). Kagi (2000) did observe ice $\mathrm{VI}$ coexisting with liquid $\mathrm{H}_{2} \mathrm{O}$ in cuboid diamond inclusions in a near-IR study at $20^{\circ} \mathrm{C}$. Zedgenizov et al., (2006) later showed that several water related components, including liquid and solid $\mathrm{H}_{2} \mathrm{O}$ polymorphs but also hydrated minerals, could be present within inclusions in a single micro-inclusion bearing diamond; therefore spectral changes in the $\mathrm{OH}$ and $\mathrm{HOH}$ regions vary sample by sample.

The high pressure $\mathrm{H}_{2} \mathrm{O}$ polymorph (ice- $\mathrm{VI}$ ) usually melts at $50-60^{\circ} \mathrm{C}$ at pressure $\sim 1.3$ GPa (Minceva-Sukarova et al., 1984). However, our IR spectra clearly indicate the presence of a high-density aqueous fluid under these conditions. Therefore, we do not see the peaks for ice-VI at the expected temperature. On cooling the sample from +50 to $-293^{\circ} \mathrm{C}$ (323 to $20 \mathrm{~K}$ ), the $\mathrm{OH}$ stretching bands at 3550 and $3150 \mathrm{~cm}^{-1}$ are gradually replaced by a primary peak at $3420 \mathrm{~cm}^{-1}$, that is characteristic of ice-VI (Bertie et al., 1968 ), and the bending vibration is split into two components indicating formation of a crystalline ice phase (Fig 3a). The crystallisation of ice $\mathrm{VI}$ is complete by $-53^{\circ} \mathrm{C}(220 \mathrm{~K})$, $\sim 40$ degrees below the solidus temperature of pure water. Ice is not expected to form at the equilibrium temperature during cooling because the sample must always be supercooled to some temperature well below the equilibrium temperature before the ice nucleates; however the freezing point may also be depressed by the presence of dissolved solutes, including $\mathrm{CO}_{2}(\mathrm{KCl}$ is not an important component of the fluid in this sample (Tomlinson 2005)). The presence of $\mathrm{CO}_{2}$ is indicated in our FTIR spectra by the characteristic stretching and bending vibrations of $\mathrm{O}=\mathrm{C}=\mathrm{O}$ molecules in spectra taken below $-50^{\circ} \mathrm{C}$ (Fig. $3 \mathrm{~b}$ ). The principal $\mathrm{CO}_{2}$ stretching peak is split into a doublet with two components at 2334 and $2345 \mathrm{~cm}^{-1}$, along with a $v_{2}$ bending vibration near $670 \mathrm{~cm}^{-1}$. The features are interpreted as being due to crystalline $\mathrm{CO}_{2}-\mathrm{I}$ phase on the basis of the $v_{3}$ splitting and the peak positions (Dows and Schettino, 1973). The pressure-temperature conditions at which $\mathrm{CO}_{2}$ is observed lie well below the melting line for solid $\mathrm{CO}_{2}$ (e.g., temperature $\sim 225^{\circ} \mathrm{C}$; pressure $\sim 2.1 \mathrm{GPa}$; Lu and Hofmeister (1995)). $\mathrm{CO}_{2}-1$ is only observed in the presence of $\mathrm{H}_{2} \mathrm{O}$ ice-VI, suggesting that it becomes dissolved at higher temperature. Methane is not observed in the infrared spectra.

\subsection{Pressure Determination inside the Diamond Inclusions}

The presence of $\alpha$-quartz (hereafter referred to as quartz) was revealed through its characteristic IR peaks at 520, 705, 783.6, 810.6, 1098 and $1167 \mathrm{~cm}^{-1}$ (Fig 1), which are assigned to the ambient PT modes at $512\left(\mathrm{~A}_{2}\right), 697(\mathrm{E}) \mathrm{cm}^{-1}, 780\left(\mathrm{~A}_{2}\right), 798(\mathrm{E}), 1084(\mathrm{E})$ and 1172 (E) (Moenke, 1974). Quartz is readily distinguished by its spectrum from other $\mathrm{SiO}_{2}$ polymorphs such as coesite or glass: $\mathrm{SiO}_{2}$ glass contains peaks at $798, \sim 1100$ and $466 \mathrm{~cm}^{-1}$ (Williams et al., 1993). It differs from the spectra obtained in this study in that its peaks are broadened and it lacks the $A_{2}$ and $E$ modes. The coesite spectrum is more complex than that of quartz, the $A_{2}$-mode doublet is less intense and is located at 795 and $814 \mathrm{~cm}^{-1}$ and there is an additional strong peak at $1225 \mathrm{~cm}^{-1}$, that appears to be absent from the sample in this study (Williams et al., 1993). Quartz has been identified in similar diamond inclusions via TEM and electron diffraction (Guthrie et al., 1991). However, the stable form of $\mathrm{SiO}_{2}$ under the likely pressure-temperature conditions for diamond formation is coesite (Bohen and Boettcher, 1982; Bose and Ganguly, 1995; Boyd and England, 1960). That phase has previously been found as single-phase inclusions within mantle diamonds (Schulze et al., 2003; Sobolev et al., 2000; Wang, 1998). 
The quartz IR spectrum has previously been calibrated to provide an internal pressure standard for studies of inclusions in minerals and for diamond cell studies (Velde and Couty, 1987; Williams et al., 1993; Wong et al., 1986). In our case, the frequency shifts of quartz modes provided a record of the internal pressure developed inside the inclusions as a function of the temperature during our heating/cooling experiments. The pressure shifts of the quartz modes at $\sim 810$ and $\sim 780 \mathrm{~cm}^{-1}$ ( $E$ and $A_{2}$ symmetry, respectively) were especially useful for this purpose. They both provide sharp peaks that are well separated from features due to the diamond or other species inside the inclusions. At ambient pressure -temperature conditions, these modes normally occur at 800.6 and $780.0 \mathrm{~cm}^{-1}$ (Wong et al., 1986). Within our diamond inclusions at room temperature, these peaks are observed at 810.6 and $783.6 \mathrm{~cm}^{-1}$ respectively, indicating a residual internal pressure $=1.3 \pm 0.1 \mathrm{GPa}$ (Wong et al., 1986). This internal pressure value is consistent with the phases of $\mathrm{H}_{2} \mathrm{O}$ and $\mathrm{CO}_{2}$ found inside the inclusions, described below. The infrared peaks are sharp, indicating that the residual pressure is homogenous across the inclusion population.

During heating and cooling cycles, the quartz peaks shifted to higher or lower wavenumber values (Fig 4a), indicating changes in the internal pressure occurring along an isochore determined by the volume inside the inclusions. This volume is expected to remain essentially constant throughout the variable temperature experiments, because the thermal expansion coefficient of diamond is very small $\left(\alpha_{V}=1.3 \times 10^{-5} \mathrm{~K}^{-1}\right)$; it would only result in a volume expansion of $0.9 \%$ during heating over 712 degrees (25 to $737^{\circ} \mathrm{C}$ ). Also, the bulk modulus (i.e., the incompressibility) of diamond is very high. During heating, the quartz $\mathrm{E}$ mode attained a value of $815.6 \mathrm{~cm}^{-1}$ at $737^{\circ} \mathrm{C}$, indicating a minimum internal pressure of $2.2 \mathrm{GPa}$ (Fig. 4b), using the calibration of Wong (1986) established at room temperature. This PT path does not intersect the diamond stability field.

We must also take account of temperature effects on the quartz mode frequencies. The $\mathrm{A}_{2}$ peak $\left(780.0 \mathrm{~cm}^{-1}\right.$ at ambient temperature and pressure) exhibits little or no shift over a wide temperature range. In our experiments, the $A_{2}$ mode broadens at high temperature and was no longer useful for pressure calibration above temperature $\sim 300^{\circ} \mathrm{C}$, but remains visible until $\sim 600^{\circ} \mathrm{C}$ (Fig. 3b). However, it served as a useful check on the internal pressure at lower temperature. The frequency of the $E$ mode $\left(800.6 \mathrm{~cm}^{-1}\right.$ at ambient pressure and temperature) shows a strong negative temperature dependence that remains approximately constant throughout the range studied here (Gervais and Piriou, 1975). We can attempt to "correct" the pressure obtained from the room temperature calibration by applying $\Delta v_{810}\left(\left(\mathrm{~cm}^{-1}\right)=-0.023 \cdot \mathrm{T}\right.$, that is valid over the range $22 \leq$ temperature $\leq 512{ }^{\circ} \mathrm{C}$ (Gervais and Piriou, 1975); the data of Ouillon et al., (2000) was used to correct for temperature $<22^{\circ} \mathrm{C}$. This approach resulted in revised quartz E-mode of $831.9 \mathrm{~cm}^{-1}$ at temperature $=737^{\circ} \mathrm{C}$ (Fig. 4a), indicating an internal pressure of $5.3 \mathrm{GPa}$ using the calibration of Wong (1986). The pressure determined from the temperature-corrected position of the $E$ mode is $10-20 \%$ higher than that calculated from the temperature-independent frequency shift values of the $A_{2}$ mode (Fig. $4 \mathrm{~b})$ at a given temperature. However, this comparison can only be made at low temperature due to the degradation and loss of the $A_{2}$ peak.

The approach used above ignores the possibility of combined pressure-temperature effects on the frequency of the $800 \mathrm{~cm}^{-1}$ quartz $E$ mode i.e. it assumes $\delta^{2} v \delta P \delta T \neq 0$. 
Sparse previous work on indicates that this assumption does hold for some quartz peaks (464 $\mathrm{cm}^{-1}$, Schmidt and Ziemann, 2000) but not for others $\left(206 \mathrm{~cm}^{-1}\right.$, Schmidt and Ziemann, 2000; $695 \mathrm{~cm}^{-1}$, Chervin et al., 2005). No data are available that could be used to evaluate the $800 \mathrm{~cm}^{-1} \mathrm{E}$ mode frequency shifts of quartz under combined highpressure high-temperature conditions. We believe that vibrational frequencies of this 800 $\mathrm{cm}^{-1} \mathrm{E}$ mode may become less temperature dependent at higher pressure, on the basis that applying the temperature correction results in an excessively large increase in the calculated pressure $\left(100 \%\right.$ at $\left.737^{\circ} \mathrm{C}\right)$, and that the pressure is significantly higher than that calculated from the $A_{2}$ mode. Our conclusion is that applying a "temperature correction" derived from temperature-shifts of the quartz $E$ mode at $1 \mathrm{~atm}$ pressure may overestimate the internal pressure inside the inclusions, and so pressures calculated along this isochore should be treated as an upper limit. In the following discussion, this upper limit is referred to as the "high" pressure-temperature path. We also give an "ideal" estimate, in which pressure is $15 \%$ lower than the "high" values; this is based on a projection of the pressure-temperature path of the temperature-insensitive $A_{2}$ mode to higher temperature (Fig. 4b).

\section{DISCUSSION}

\subsection{Conditions in the mantle}

The IR data are consistent with liquid $\mathrm{H}_{2} \mathrm{O}$; there is no evidence of a hydrous-silicate melt (glass) phase or of $\mathrm{H}_{2} \mathrm{O}$ dissolved in melt in this sample. This then means that the pressure -temperature conditions within the diamond growth region of the mantle were subsolidus, placing important constraints on the diamond formation conditions. The pressure-temperature range for the existence of free $\mathrm{H}_{2} \mathrm{O}$ fluid in the mantle is bounded by the stability fields of hydrous minerals occurring at low temperature and the $\mathrm{H}_{2} \mathrm{O}$ saturated solidus at high temperature (Kawamoto and Holloway, 1997). This range of conditions is compatible with conditions along the "ideal" and "high" pressuretemperature paths of the inclusions during our calibrated high-temperature FTIR studies (Fig. 5). For the "ideal" pressure-temperature path, the temperature is constrained to below $1020^{\circ} \mathrm{C}$ within a $\mathrm{H}_{2} \mathrm{O}+$ peridotite mantle (Kawamoto and Holloway, 1997), and to temperature $<1100^{\circ} \mathrm{C}$ for an $\mathrm{H}_{2} \mathrm{O}+$ eclogite mantle (Kessel et al., 2005). The maximum temperature increases to $\sim 1200^{\circ} \mathrm{C}$ when using the "high" pressure estimates. Both the peridotite and eclogite solidii were determined from experiments in natural analogue compositions containing $\mathrm{Na}_{2} \mathrm{O}$; alkalis have been shown to lower the solidus temperature in both peridotite (Dasgupta and Hirschmann 2007) and eclogite (Dasgupta and Hirschmann 2005) and are likely to contribute to the salinity of the trapped fluid. The inclusions also contain carbonate and a small amount of free $\mathrm{CO}_{2}$ Experiments with natural carbonated peridotite show that solidus temperatures increases with increasing bulk $\mathrm{CO}_{2}$ and may be $\sim 100^{\circ} \mathrm{C}$ higher in $\mathrm{CO}_{2}$ saturated peridotite (Dasgupta and Hirschmann 2007).

To estimate the likely conditions of growth, we need to determine the pressure and temperature at which the "high" and "ideal" isochores intersect the mantle geotherm. The Mbuji-Mayi kimberlite cluster from which the present diamond sample was obtained is located on the $\sim 2.7 \mathrm{Ga}$ Kasai craton (e.g., Demaiffe et al., (1991)) in southern Democratic Republic of Congo. Artemieva and Mooney $(2001,2006)$ have suggested that "young" Archean (3.0-2.6 Ga) lithosphere is typically $>250 \mathrm{~km}$ thick with a geothermal gradient of $35-38 \mathrm{~mW} / \mathrm{m}^{2}$. A $37 \mathrm{~mW} / \mathrm{m}^{2}$ average geotherm for the Mbuji Mayi kimberlites is supported by equilibration temperatures of peridotite and eclogite xenoliths from the Kundelungu kimberlite, Congo (data from Table 10, Kampata (1995)), which lie close to a $37 \mathrm{~mW} / \mathrm{m}^{2}$ geotherm (Pollack and Chapman, 1977). The peak 
temperature attained in our FTIR experiment was $737^{\circ} \mathrm{C}$; under these conditions the internal pressure of the inclusions reached a maximum internal pressure of $5.3 \mathrm{GPa}$ along the "high" isochore; and of $\sim 4.0 \mathrm{GPa}$ along the "ideal" isochore The "ideal" isochore from the diamond inclusions intersects the $37 \mathrm{mWm}^{-2}$ geotherm at pressure $\sim 5$ GPa and temperature $\sim 1000^{\circ} \mathrm{C}$, i.e., below the peridotite $+\mathrm{H}_{2} \mathrm{O}$ solidus (Kawamoto and Holloway, 1997; Wyllie and Ryabchikov, 2000) and eclogite $+\mathrm{H}_{2} \mathrm{O}$ solidus (Kessel et al., 2005). This is consistent with the observed presence of liquid water in the inclusions, indicating that the primary $\mathrm{C}-\mathrm{O}-\mathrm{H}$ fluid would have been equilibrium with a sub-solidus mantle during diamond growth. A $40 \mathrm{mWm}^{-2}$ geotherm would be intersected at $5.7 \mathrm{GPa}$ and $1190^{\circ} \mathrm{C}$, well above the solidus of $\mathrm{H}_{2} \mathrm{O}$-bearing peridotite and eclogite, this is not consistent with the observed coexistence of silicate mineral phases and liquid water. When the "high" pressure values are used, both geotherms are intersected above the mantle $+\mathrm{H}_{2} \mathrm{O}$ solidus, which is not consistent with the observation of liquid water in the inclusions.

The presence of both $\mathrm{CO}_{2}$ and $\mathrm{CO}_{3}{ }^{2-}$ species (carbonate minerals) within the inclusions indicates that the original fluid from which the diamond crystallized was oxidized. Diamond formation can occur from the breakdown of $\mathrm{CO}_{2}$ to $\mathrm{C}+\mathrm{O}_{2}$ (i.e., at the $\mathrm{CCO}$ buffer), for example when associated with oxidation of $\mathrm{Fe}^{2+}$-bearing minerals in the surrounding rocks (McCammon et al., 2004). Hydrogen is also present in the sample inclusions; $\mathrm{C}-\mathrm{O}-\mathrm{H}$ fluid in equilibrium with graphite/diamond is essentially $\mathrm{H}_{2} \mathrm{O}-\mathrm{CO}_{2}$ along the oxidized side of the graphite saturation field (Holloway and Blank 1994), reaching a maximum $\mathrm{H}_{2} \mathrm{O}$ content approximately $2 \log \mathrm{fO}_{2}$ units below the $\mathrm{CCO}$ buffer. Experimentally, diamond precipitation in the presence of oxidising $\mathrm{H}_{2} \mathrm{O}-\mathrm{CO}_{2}$ fluids has been observed at temperature $>1200^{\circ} \mathrm{C}$ and pressure $=5-7 \mathrm{GPa}$ (Akaishi et al., 2000; Sokol et al., 2001). Under more reducing conditions, $\mathrm{C}-\mathrm{O}-\mathrm{H}$ fluids are $\mathrm{H}_{2} \mathrm{O}-\mathrm{CH}_{4} ; \mathrm{CO}_{2}$ and $\mathrm{CH}_{4}$ are not expected to coexist except close to the $\mathrm{H}_{2} \mathrm{O}$ maximum. The coexistence of oxidized carbon, neutral carbon and $\mathrm{H}_{2} \mathrm{O}$, and the absence of $\mathrm{CH}_{4}$ in this diamondinclusion system constrain the oxidation conditions to of diamond formation to below the $\mathrm{CCO}$ buffer and above the $\mathrm{H}_{2} \mathrm{O}$ maximum. This gives a window of -1 to $-3 \log \mathrm{fO}_{2}$ relative to the quartz-fayalite-magnetite (QFM) buffer at $4.5 \mathrm{GPa}$ and $1000^{\circ} \mathrm{C}$ (Simakov 1998).

\subsection{Inclusion-forming processes along the isochore}

Our interpretation of the experimental results from the heating/cooling experiments carried out on the diamond inclusions depend on an assumption that the inclusions did not rupture or leak during the diamond's ascent to the surface. The recorded increase in internal pressure of the inclusions during heating shown by the shift of the E-mode to higher wavenumbers indicates that the inclusions are now sealed; however this does not rule out the possibility that the inclusions were ruptured ${ }^{1}$ and subsequently resealed. The

\footnotetext{
${ }^{1}$ This issue is addressed by a linear model for the behaviour of the diamond-inclusions system, which predicts that rupture of the inclusions has occurred if the remnant pressure of $\mathrm{H}_{2} \mathrm{O}$ inclusions at room temperature is $<1.5 \mathrm{GPa}$ (Barron, 2005). This critical remnant pressure is slightly higher than the internal pressure of the inclusions in this study $(1.3 \mathrm{GPa})$ calculated using the calibration of Wong et al., (1986) at room temperature. Note that the pressure calibrations of Williams et al., (1993) and Velde and Couty (1987 give internal pressures of 1.5 and $2.0 \mathrm{GPa}$ respectively for our sample, due to imprecision in the position of the quartz E-mode at room temperature $\left(800.6 \mathrm{~cm}^{-1}\right.$ Wong et al., $1986 ; 800 \mathrm{~cm}^{-1}$ Williams et al $1993 ; 779 \mathrm{~cm}^{-1}$ Velde and
} 
linear model of Barron (2005) predicts a formation pressure (or resealing pressure in the case of ruptured inclusions) of $1.8 \mathrm{GPa}$ for the observed residual pressure of $1.3 \mathrm{GPa}$ and a formation temperature of $1000-1100^{\circ} \mathrm{C}$. Such pressure-temperature conditions are significantly below the diamond stability field. We conclude that our diamond samples did not suffer rupture/resealing after their initial formation and closure under mantle pressure-temperature conditions. Furthermore, inclusion rupture is considered unlikely in our diamond because of the extremely small size of the inclusions (generally $\leq 0.5 \mu \mathrm{m}$; Guthrie et al., (1991)), and because of the relatively constant densities indicated by the narrow width of the quartz peaks.

The mantle $\mathrm{C}-\mathrm{O}-\mathrm{H}$ fluid that gave rise to the diamond studied here must have contained dissolved $\mathrm{SiO}_{2}$. Silicate is highly soluble in $\mathrm{H}_{2} \mathrm{O}$-rich fluids at high temperature and high pressure (Stalder et al., 2001; Kessel et al., 2005). Manning (1994) derived an expression for the equilibrium constant of for the dissolution of quartz in water at up to $900^{\circ} \mathrm{C}$ and $2.0 \mathrm{GPa}$. Manning (1994) states that the expression may be extrapolated to higher pressure if the isothermal variation of $\log m_{\mathrm{SiO} 2(\mathrm{aq})}$ with $\log \rho_{\mathrm{H} 2 \mathrm{O}}$ is assumed to be linear. Extrapolating this expression to $5.0 \mathrm{GPa}$ and $1000^{\circ} \mathrm{C}$ gives a value of $6.6 \mathrm{~mol} / \mathrm{kg}$ for the solubility of $\mathrm{SiO}_{2}$ in water. Using densities of 2.65 and $1.2 \mathrm{gcm}^{-3}$ for quartz and water respectively, we can calculate the relative volumes of each phase that should be present in $\mathrm{H}_{2} \mathrm{O}-\mathrm{SiO}_{2}$ bearing inclusions at ambient conditions (room temperature and 1.3 $\mathrm{GPa}$ ). This simple calculation suggests that if the inclusions contain less than $15 \% \mathrm{SiO}_{2}$, then all $\mathrm{SiO}_{2}$ is expected to have been in solution at the conditions of diamond growth. TEM images of inclusions in similar micro-inclusion bearing diamonds have shown that the total population of mineral phases only occupy a fraction of the inclusions (Guthrie et al., 1991; Klein-BenDavid et al., 2006). Therefore, it is likely that $\mathrm{SiO}_{2}$ in the inclusions was dissolved in the fluid at the time of entrapment and subsequently precipitated as daughter minerals during cooling and depressurisation following kimberlite eruption.

It seems likely that the $\mathrm{SiO}_{2}$ phase present within the inclusions originally precipitated from the fluid as coesite, because that phase is thermodynamically stable above $400^{\circ} \mathrm{C}$, and the solubility of $\mathrm{SiO}_{2}$ in $\mathrm{H}_{2} \mathrm{O}$-rich fluid decreases by an order of magnitude between $700^{\circ} \mathrm{C}$ and $400^{\circ} \mathrm{C}$ (Manning, 1994) (Fig. 5). However, the coesite subsequently transformed into quartz following eruption and long-term cooling at low pressure, as the diamond was entrained in the host kimberlite. However, fluids are well known to have a catalytic effect on reactions; the coesite $\rightarrow$ quartz growth rates determined by Perrillat (2003) are an order of magnitude faster than those of Mosenfelder (1997), this difference is attributed to the possible presence of fluids in the experimental system of Perrillat (2003) by Mosenfelder (2005) and Lathe et al., (2005). Lathe et al., (2005) show that the rate of coesite-to-quartz transformation is $10 \mathrm{x}$ faster in the presence of water. It is likely that coesite tranformed into quartz during the relatively long timescales spent at low pressure-temperature conditions during eruption and subsequent cooling at ambient pressure, within the host magma.

The quartz phase was not observed to transform back into coesite during the timescale of our laboratory heating experiments. The "ideal" inclusion isochore crosses the quartzcoesite equilibrium line at $280-380^{\circ} \mathrm{C}$ and $2.6 \mathrm{GPa}$, and some coesite formation is predicted to have occurred. Growth rate is exponentially dependent on temperature; at

Couty 1987. Therefore, the internal pressure in our sample is considered to be close to, and within error of, the critical remnant pressure above which rupture is unlikely to have occurred. 
$700^{\circ} \mathrm{C}$, the growth rate of coesite from quartz is $7.9 \times 10^{-10} \mathrm{~m} / \mathrm{s}$ (Perrillat et al., 2003). In our heating experiments, the sample spent $\sim 15$ minutes above $700^{\circ} \mathrm{C}$. However, reactions close to the phase boundary may be inhibited by slow nucleation kinetics (Mosenfelder and Bohen, 1997). Furthermore, there is only a small energy difference $(\Delta \mathrm{H} \approx 8.2 \mathrm{KJ} / \mathrm{mol})$ between $\alpha$-quartz and coesite, this means it may be possible for $\alpha$ quartz to exist metastably in the coesite stability field because the driving force of the transformation is small compared to the activation energy (Zinn et al., 1997). Therefore, we suggest that re-heating during our high-temperature laboratory experiments occurred too rapidly for back transformation to coesite to occur. We did observe some reduction in the absorbance intensity of the quartz IR peaks with increasing temperature (Fig. 3b), that is consistent with a reduction in quantity of the crystals present. That could indicate some re-dissolution of the $\mathrm{SiO} 2$ phase in the fluid at high $\mathrm{T}$. It might also signal some degradation in crystal quality, that could be associated with premonitory effects of a solid-state transformation into the more stable coesite phase under high-pressure, hightemperature conditions.

\section{CONCLUSION}

The infrared spectra of a micro-inclusion bearing diamond sample indicate that its inclusions contain a variety of mineral phases (quartz, phlogopite, apatite and carbonate), along with a fluid phase comprising liquid $\mathrm{H}_{2} \mathrm{O}$ and a minor $\mathrm{CO}_{2}$.

At room temperature, the internal pressure within the inclusions was $1.3+/-0.1 \mathrm{GPa}$. At $737^{\circ} \mathrm{C}$, the pressure inside the micro-inclusions reached 4.0 to $5.3 \mathrm{GPa}$, close to the pressure-temperature conditions obtained during the initial diamond precipitation and entrapment of the fluid. At these conditions, the mantle $\mathrm{C}-\mathrm{O}-\mathrm{H}$ fluid contained dissolved solutes, such as $\mathrm{SiO}_{2}$. These solutes subsequently precipitated from the $\mathrm{C}-\mathrm{O}-\mathrm{H}$ fluid, forming daughter minerals in the inclusions. Reduction of $\mathrm{CO}_{2}$ by reactions between the oxidizing fluid and mantle minerals led to the precipitation of diamond.

Our pressure-calibrated FTIR studies of $\mathrm{H}_{2} \mathrm{O}-\mathrm{CO}_{2}$ bearing inclusions within the sample allow us to retrace the pressure-temperature path followed by the remnant mantle fluid that gave rise to the diamonds following precipitation of the host diamond, during its entrainment in erupting kimberlite magma and its subsequent slow cooling within the host kimberlite at the Earth's surface.

Acknowledgements: ELT was funded by an EPSRC industrial CASE award with DeBeers. PFM acknowledges support from the EPSRC and also from a Wolfson-Royal Society Research Merit Award Fellowship. Dr Judith Milledge is thanked for providing the sample. Professor Robert Bodnar and Dr Jean Dubessy are thanked for constructive reviews of this manuscript. 


\section{REFERENCES}

Akaishi M., Kumar M. D. S., Kanda H., and Yamaoka S. (2000) Formation process of diamond from supercritical $\mathrm{H}_{2} \mathrm{O}-\mathrm{CO}_{2}$ fluid under high pressure and high temperature conditions. Diamond and Related Materials 9(12), 1945-1950.

Artemieva I. M. (2006) Global $1^{\circ} \times 1^{\circ}$ thermal model TC1 for the continental lithosphere: Implications for lithosphere secular evolution. Tectonophysics 416(1-4), 245-277.

Artemieva I. M. and Mooney W. D. (2001) Thermal thickness and evolution of Precambrian lithosphere: A global study. Journal of Geophysical Research-Solid Earth 106(B8), 16387-16414.

Barron L. M. (2005) A linear model and topology for the host-inclusion mineral system involving diamond. Canadian Mineralogist 43, 203-224.

Beran A. (2002) Infrared Spectroscopy of Micas. In Micas: Crystal Chemistry and Metamorphic Petrology, Vol. 46 (ed. A. Mottana, F. P. Sassi, J. B. Thompson, and S. Guggenheim), pp. 351-370. Mineralogical Society of America.

Berman R. and Simon R. (1955) On the Graphite-Diamond Equilibrium. Zeit. Elektrochem. 59, 333-338.

Bertie J. E., Labbe H. J., and Whalley E. (1968) Infrared spectrum of ice VI in the range 4000-50 cm-1. The Journal of Chemical Physics 49(5), 2141-2144.

Bohen S. R. and Boettcher A. L. (1982) The quartz-coesite transformation: A precise determination and the effects of other components. Journal of Geophysical Research 87, 7073-7078.

Bose K. and Ganguly J. (1995) Quartz-coesite transition revisited: Reversed experimental determination at $500-1200^{\circ} \mathrm{C}$ and retrieved thermodynamic properties. American Mineralogist 80, 231-238.

Boyd F. R. and England J. L. (1960) The quartz-coesite transition. Journal of Geophysical Research 65, 749-756.

Bridgman P. W. (1935) The Phase Diagram of Water to $45,000 \mathrm{~kg} / \mathrm{cm}^{2}$. Journal of Chemical Physics 5, 964-966.

Bundy F. P., Strong H. M., Bovenkerk H. P., and Wentorf R. H. (1961) DiamondGraphite Equilibrium Line from Growth and Graphitization of Diamond. Journal of Chemical Physics 35(2), 383-\&.

Chervin J. C., Power C., and Polian A. (2005) Quartz as a pressure sensor in the infrared. High Pressure Research 25(2), 97-105.

Chrenko R. M., McDonald R. S., and Darrow K. A. (1967) Infra-Red Spectra of Diamond Coat. Nature 213(5075), 474-\&.

Dasgupta R. and Hirschmann M. M. (2007) Effect of variable carbonate concentration on the solidus of mantle peridotite. American Mineralogist 92(2-3), 370-379.

Dasgupta R., Hirschmann M. M., and Dellas N. (2005) The effect of bulk composition on the solidus of carbonated eclogite from partial melting experiments at $3 \mathrm{GPa}$. Contributions to Mineralogy and Petrology 149(3), 288-305.

Datchi F., Loubeyre P., and LeToullec R. (2000) Extended and accurate determination of the melting curves of argon, helium, ice $\left(\mathrm{H}_{2} \mathrm{O}\right)$, and hydrogen $\left(\mathrm{H}^{-2}\right)$. Physical Review B 61(10), 6535-6546.

Demaiffe D., Fieremans M., and Fieremans C. (1991) The kimberlites of central Africa: A review. In Magmatism in Extensional Structural Settings (ed. A. B. Kampunzu and R. T. Lubala), pp. 537-559. Springer-Verlag.

Dows, D.A. and Schettino, V. (1973) Two-phonon infrared abrorption spectra in crystalline carbon dioxide. Journal of Chemical Physics 58 (11), 5009-5016.

Farmer V. C. (1974) The layer silicates. In The infrared spectra of minerals (ed. V. C. Farmer), pp. 331-365. Mineralogical Society. 
Fei Y. W., Mao H. K., and Hemley R. J. (1993) Thermal Expansivity, Bulk Modulus, and Melting Curve of $\mathrm{H}_{2} \mathrm{O}-\mathrm{Ice}$ Vii to $20 \mathrm{GPa}$. Journal of Chemical Physics 99(7), 5369-5373.

Gervais F. and Piriou B. (1975) Temperature-Dependence of Transverse and Longitudinal Optic Modes in Alpha-Phases and Beta-Phases of Quartz. Physical Review B 11(10), 3944-3950.

Guthrie G. D., Veblen D. R., Navon O., and Rossman G. R. (1991) Sub-micrometer Fluid Inclusions in Turbid-Diamond Coats. Earth and Planetary Science Letters 105(13), 1-12.

Izraeli E. S., Harris J. W., and Navon O. (2001) Brine inclusions in diamonds: a new upper mantle fluid. Earth and Planetary Science Letters 187(3-4), 323-332.

Kagi H., Kiyasu A., Akagi T., Nara M., and Sawaki T. (2006) Near-infrared spectroscopic determination of salinity and internal pressure of fluid inclusions in minerals. Applied Spectroscopy 60(3), 430-436.

Kagi H., Lu R., Davidson P., Goncharov A. F., Mao H. K., and Hemley R. J. (2000) Evidence for ice $\mathrm{VI}$ as an inclusion in cuboid diamonds from high pressure temperature near infrared spectroscopy. Mineralogical Magazine 64(6), 10891097.

Kamiya Y. and Lang A. R. (1965) On the structure of coated diamonds. Philosophical Magazine 11, 347-357.

Kampata M. D., Moreau J., Hertogen J., Demaiffe D., Condliffe E., and Mvuemba N. F. (1995) Megacrysts and ultramafic xenoliths from Kundelungu kimberlites (Shaba, Zaire). Mineralogical Magazine 59(397), 661-676.

Kawamoto T. and Holloway J. R. (1997) Melting temperature and partial melt chemistry of $\mathrm{H}_{2} \mathrm{O}$-saturated mantle peridotite to 11 gigapascals. Science 276(5310), 240243.

Kennedy C. S. and Kennedy G. C. (1976) The equilibrium boundary between graphite and diamond. Journal of Geophysical Research 81, 2467-2470.

Kessel R., Ulmer P., Schmidt M. W., and Thompson A. B. (2005) The water basalt system at 4 to $6 \mathrm{GPa}$ : Phase relations and second critical endpoint in a K-free eclogite at 700 to $1400^{\circ} \mathrm{C}$. Earth and Planetary Science Letters 237(3-4), 873892.

Klein-BenDavid O., Wirth R., and Navon O. (2006) TEM imaging and analysis of microinclusions in diamonds: A close look at diamond-growing fluids. American Mineralogist 91(2-3), 353-365.

Lang A. R. and Walmsley J. C. (1983) Apatite Inclusions in Natural Diamond Coat. Physics and Chemistry of Minerals 9(1), 6-8.

Lathe C., Koch-Muller M., Wirth R., Westrenen W., Muller H.-J., Schilling F., and Lauterjung J. (2005) The influence of $\mathrm{OH}$ in coesite on the kinetics of the coesitequartz phase transition. American Mineralogist 90, 36-43.

Lu R. and Hofmeister A. M. (1995) Infrared Fundamentals and Phase-Transitions in $\mathrm{CO}_{2}$ up to 50 Gpa. Physical Review B 52(6), 3985-3992.

Manning C. E. (1994) The Solubility of Quartz in $\mathrm{H}_{2} \mathrm{O}$ in the Lower Crust and UpperMantle. Geochimica Et Cosmochimica Acta 58(22), 4831-4839.

McCammon C. A., Stachel T., and Harris J. W. (2004) Iron oxidation state in lower mantle mineral assemblages - II. Inclusions in diamonds from Kankan, Guinea. Earth and Planetary Science Letters 222(2), 423-434.

Minceva-Sukarova B., Sherman W. F., and Wilkinson G. R. (1984) The raman spectra of ice (Ih, II, III, V, VI and IX) as functions of pressure and temperature. Journal of Chemical and Solid State Physics 17, 5883-5850. 
Moenke H. H. W. (1974) Silica, the three-dimensional silicates, borosilicates and berylium silicates. In The infrared spectra of minerals (ed. V. C. Farmer), pp. 365382. Mineralogical Society.

Mosenfelder J. L. and Bohen S. R. (1997) Kinetics of the coesite to quartz transformation. Earth and Planetary Science Letters 153(1-2), 133-147.

Mosenfelder J. L., Schertl H.-P., Smyth J. R., and Liou J. G. (2005) Factors in the preservation of coesite: The importance of fluid infiltration. American Mineralogist 90, 779-789.

Navon O. (1991) High Internal-Pressures in Diamond Fluid Inclusions Determined by Infrared-Absorption. Nature 353(6346), 746-748.

Navon O., Hutcheon I. D., Rossman G. R., and Wasserburg G. J. (1988) Mantle-derived fluids in diamond micro-inclusions. Nature 335, 784-789.

Ouillon R., Pinan-Lucarre J. P., and Ranson P. (2000) Anharmonicity of zone-centre optical phonons: Raman spectra of the isomorphous alpha-quartz, berlinite and gallium phosphate in the temperature range $8-300 \mathrm{~K}$. Journal of Raman Spectroscopy 31(7), 605-613.

Pal'yanov, Y. N., Sokol, A. G., Borzdov, Y. M. and Khokhryakov, A. F. (2002) Fluidbearing alkaline carbonate melts as the medium for the formation of diamonds in the Earths mantle: An experimental study. Lithos 60 (3-4), 145-159.

Perrillat J. P., Daniel I., Lardeaux J. M., and Cardon H. (2003) Kinetics of the coesitequartz transition: Application to the exhumation of ultrahigh-pressure rocks. Journal of Petrology 44(4), 773-788.

Pollack H. N. and Chapman D. S. (1977) On the regional variation of heat flow, geotherms, and lithospheric thickness. Tectonophysics 38, 279-296.

Roedder E. (1984) Fluid Inclusions. Mineralogical Society of America.

Ross S. D. (1974) Phosphates and other oxy-anions of group V. In The infrared spectra of minerals (ed. V. C. Farmer), pp. 383-422. Mineralogical Society.

Schmidt C. and Ziemann M. A. (2000) In-situ Raman spectroscopy of quartz: A pressure sensor for hydrothermal diamond-anvil cell experiments at elevated temperature. American Mineralogist 85, 1725-1734.

Schulze D. J., Harte B., Valley J. W., Brenan J. M., and Channer D. M. D. (2003) Extreme crustal oxygen isotope signatures preserved in coesite in diamond. Nature 423(6935), 68-70.

Simakov S. K. (1998) Redox state of Earth's upper mantle peridotites under the ancient cratons and its connection with diamond genesis. Geochimica Et Cosmochimica Acta 62(10), 1811-1820.

Sobolev N. V., Fursenko B. A., Goryainov S. V., Shu J. F., Hemley R. J., Mao H. K., and Boyd F. R. (2000) Fossilized high pressure from the Earth's deep interior: The coesite-in-diamond barometer. Proceedings of the National Academy of Sciences of the United States of America 97(22), 11875-11879.

Sokol A. G., Pal'yanov Y. N., Pal'yanova G. A., Khokhryakov A. F., and Borzdov Y. M. (2001) Diamond and graphite crystallization from C-O-H fluids under high pressure and high temperature conditions. Diamond and Related Materials 10(12), 2131-2136.

Stalder R., Ulmer P., and Gunther D. (2001) Fluids in the system forsterite-phlogopite$\mathrm{H}_{2} \mathrm{O}$ at 60 kbar. Contributions to Mineralogy and Petrology 140(1), 607-618.

Tomlinson E. L., Jones A. P., and Harris J. W. (2006) Co-existing fluid and silicate inclusions in mantle diamond. Earth and Planetary Science Letters 250(3-4), 581-595. 
Tomlinson, E.L. (2005). The role of fluids in the growth of fibrous diamonds: a study of African and Canadian coated diamonds. Unpublished PhD thesis, University College London.

Velde B. and Couty R. (1987) High-pressure infrared spectra of silica glass and quartz. Journal of Non-Crystalline Solids 94, 238-250.

Walmsley J. C. and Lang A. R. (1992a) On Sub-micrometer Inclusions in Diamond Coat - Crystallography and Composition of Ankerites and Related Rhombohedral Carbonates. Mineralogical Magazine 56(385), 533-543.

Walmsley J. C. and Lang A. R. (1992b) Oriented Biotite Inclusions in Diamond Coat. Mineralogical Magazine 56(382), 108-111.

Wang W. (1998) Formation of diamond with mineral inclusions of "mixed" eclogite and peridotite paragenesis. Earth and Planetary Science Letters 160(3-4), 831-843.

White. (1974) The carbonate minerals. In The infrared spectra of minerals (ed. V. C. Farmer), pp. 227-284. Mineralogical Society.

Williams Q., Hemley R. J., Kruger M. B., and Jeanloz R. (1993) High-Pressure InfraredSpectra of Alpha-Quartz, Coesite, Stishovite and Silica Glass. Journal of Geophysical Research-Solid Earth 98(B12), 22157-22170.

Wong P. T. T., Baudais F. L., and Moffatt D. J. (1986) Hydrostatic-Pressure Effects on to-Lo Splitting and Softening of Infrared Active Phonons in Alpha-Quartz. Journal of Chemical Physics 84(2), 671-674.

Wyllie P. J. and Ryabchikov I. D. (2000) Volatile components, magmas, and critical fluids in upwelling mantle. Journal of Petrology 41(7), 1195-1206.

Zedgenizov D. A., Shiryaev A. A., Shatsky V. S., and Kagi H. (2006) Water-related IR characteristics in natural fibrous diamonds. Mineralogical Magazine 70, 219-229.

Zinn P., Hinze E., Lauterjung J., and Wirth R. (1997) Kinetic and microstructural studies of the quartz-coesite phase transition. Physics and Chemistry of the Earth 22(12), 105-111. 


\section{FIGURE HEADINGS}

Figure 1. Photograph showing the high inclusion density and opacity of the diamond sample. The inset shows the octahedral morphology of the whole sample before cutting.

Figure 2. IR spectra of the diamond sample at room temperature (black line) compared with that of a typical inclusion-free type laA diamond (grey line). The inset shows an enlargement of the $400-1000 \mathrm{~cm}^{-1}$ region. Mineral and fluid species assignments (3): $\mathrm{H}_{2} \mathrm{O}, \mathrm{CO}_{2}$, qz - quartz, carb - carbonate, sil - silicate, ap - apatite.

Figure 3. IR spectra of the diamond arranged vertically according to temperature $\left({ }^{\circ} \mathrm{C}\right)$ : a) whole spectra; b) enlarged to show evolution of the $\mathrm{OH}$ bending $\left(1550-1750 \mathrm{~cm}^{-1}\right)$ and stretching (2800-3800 $\mathrm{cm}^{-1}$ ) spectra, and c) enlarged regions relevant to $\mathrm{CO}_{2}, \mathrm{CO}_{3}$ and silicate minerals.

Figure 4. (a) Position of the quartz peaks with increasing temperature: uncorrected Emode (blank diamonds), E-mode corrected for the effect of temperature (open diamonds) using the temperature calibrations of Gervais and Piriou (1975) and Ouillon et al., (2000), and $A_{2}$-mode (black squares). (b) Pressure calculated from the uncorrected E-mode (black diamonds) which gives a "low" internal pressure, from the temperature corrected E-mode (open diamonds), which gives a "high" pressure, and from the $A_{2}$ mode (black squares); the position of the $A_{2}$ mode could not be determined above $300^{\circ} \mathrm{C}$. Pressure is calculated using the calibration of Wong et al., (1986). The "ideal" isochore is shown as a dashed blank line; this is between the "low" and "high" paths.

Figure 5. Low (black diamonds), high (open diamonds) and ideal (grey circles) inclusion pressure-temperature paths during formation/eruption and subsequent laboratory reheating. Also shown are the $\mathrm{H}_{2} \mathrm{O}$ solidus (Datchi et al., 2000) and phase transitions (black lines) (Minceva-Sukarova et al., 1984), $\mathrm{CO}_{2}$ solidus (long black dashes) (Lu and Hofmeister, 1995) and $\mathrm{SiO}_{2}$ phase transitions (short black dashes) (Bose and Ganguly, 1995). The inset shows solubility of $\mathrm{SiO}_{2}$ in water $\left(\times 10^{-2} \mathrm{~mol} / \mathrm{kg}\right)$ along the "ideal" isochore (grey circles) for a constant density of $1.3 \mathrm{gcm}^{-3}$ calculated every $100^{\circ} \mathrm{C}$ using the equation of Manning (1994). Also shown: black line - graphite-diamond equilibrium line (Berman and Simon, 1955); short black dashes - quartz-coesite equilibrium line (Bose and Ganguly 1995); black squares - formation conditions of xenoliths from Congo (Kampata et al., 1995); grey line - the $37 \mathrm{mWm}^{-2}$ craton geotherm; short grey dashes the $40 \mathrm{mWm}^{-2}$ craton geotherm (Pollack and Chapman, 1977); long grey dashes $-\mathrm{H}_{2} \mathrm{O}$ Iherzolite solidus (Kawamoto and Holloway, 1997); grey stippled line - likely kimberlite eruption path (thick red line). The grey circle indicates the likely pressure -temperature conditions of diamond precipitation. 


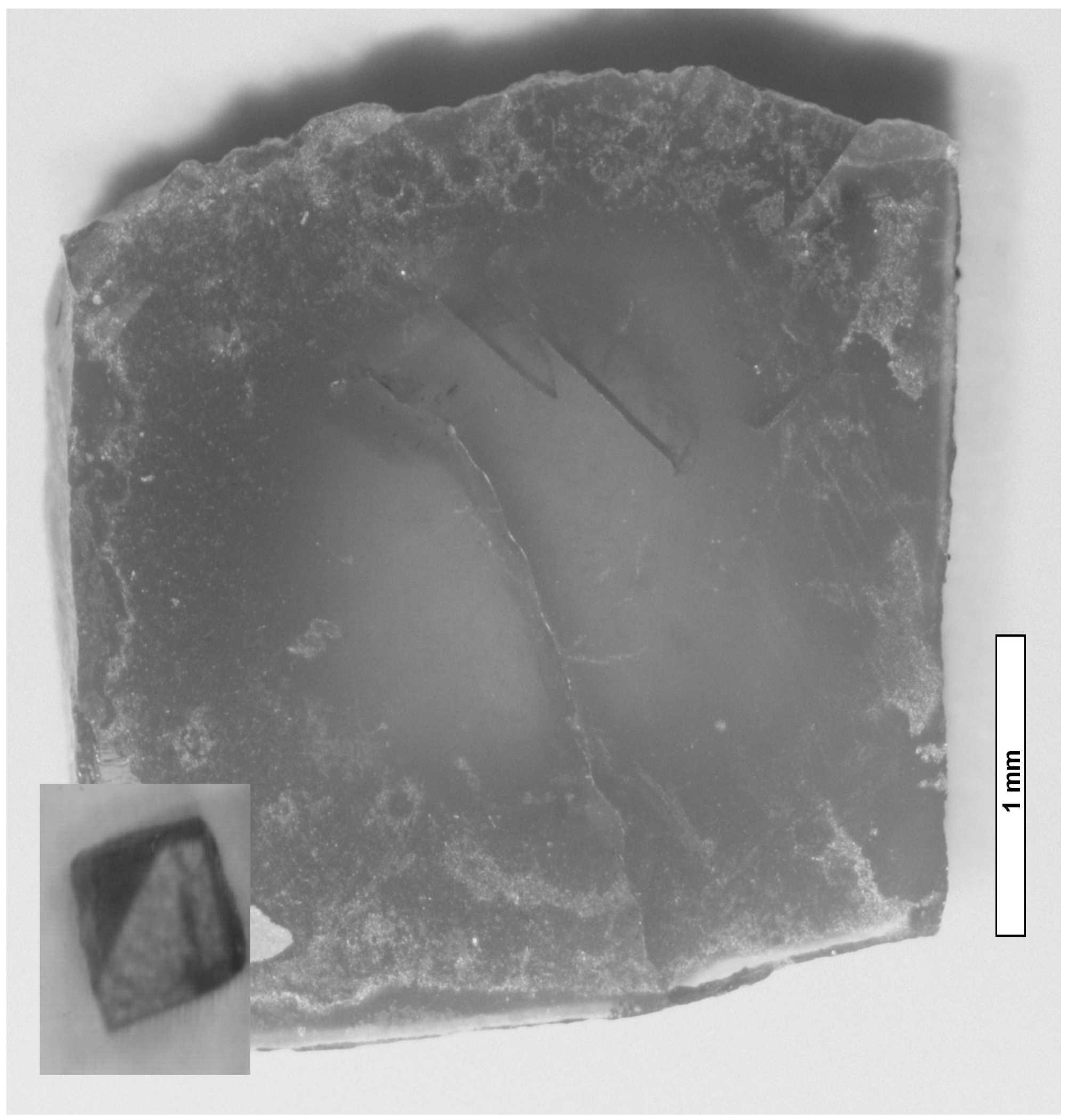




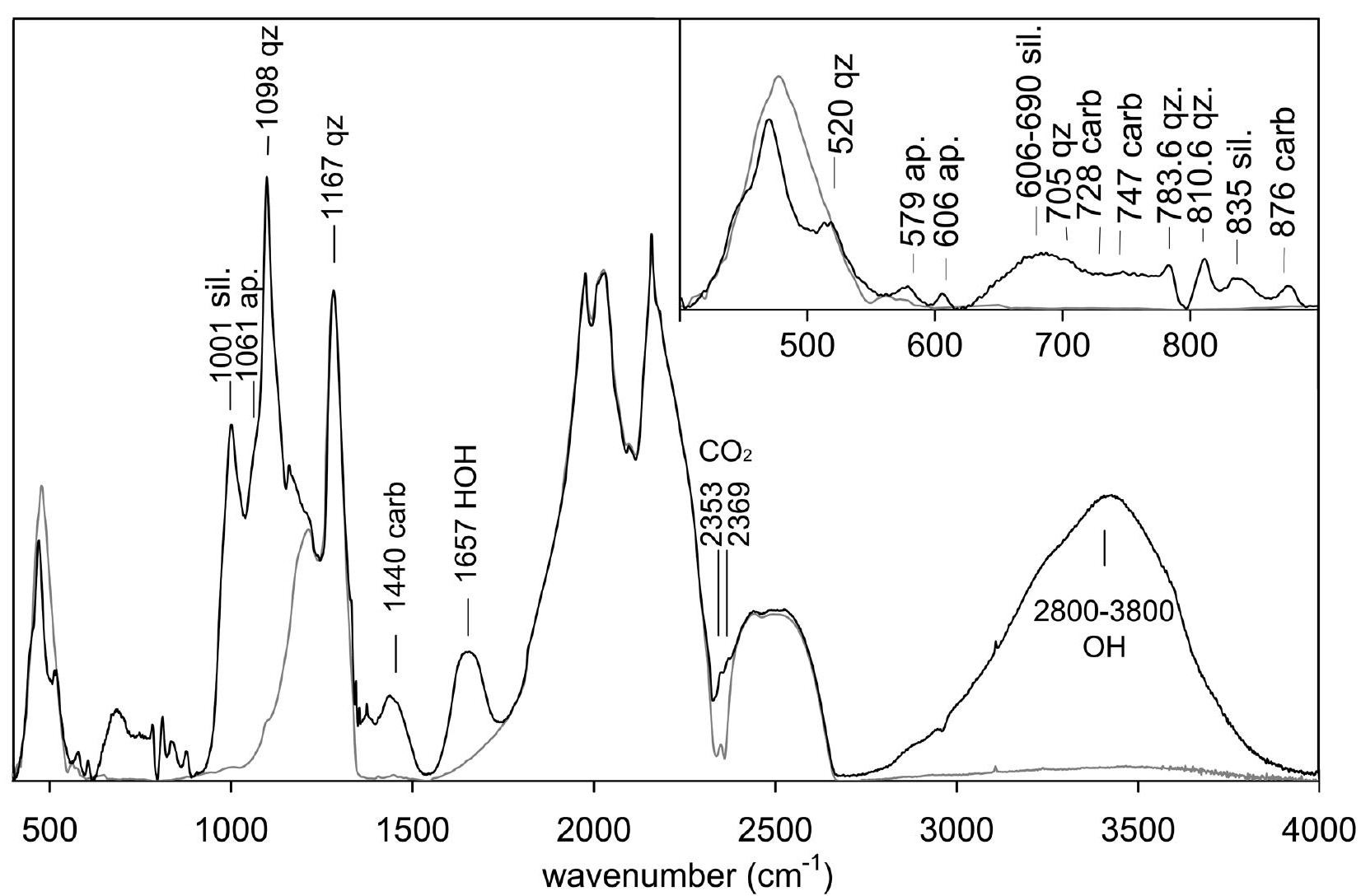




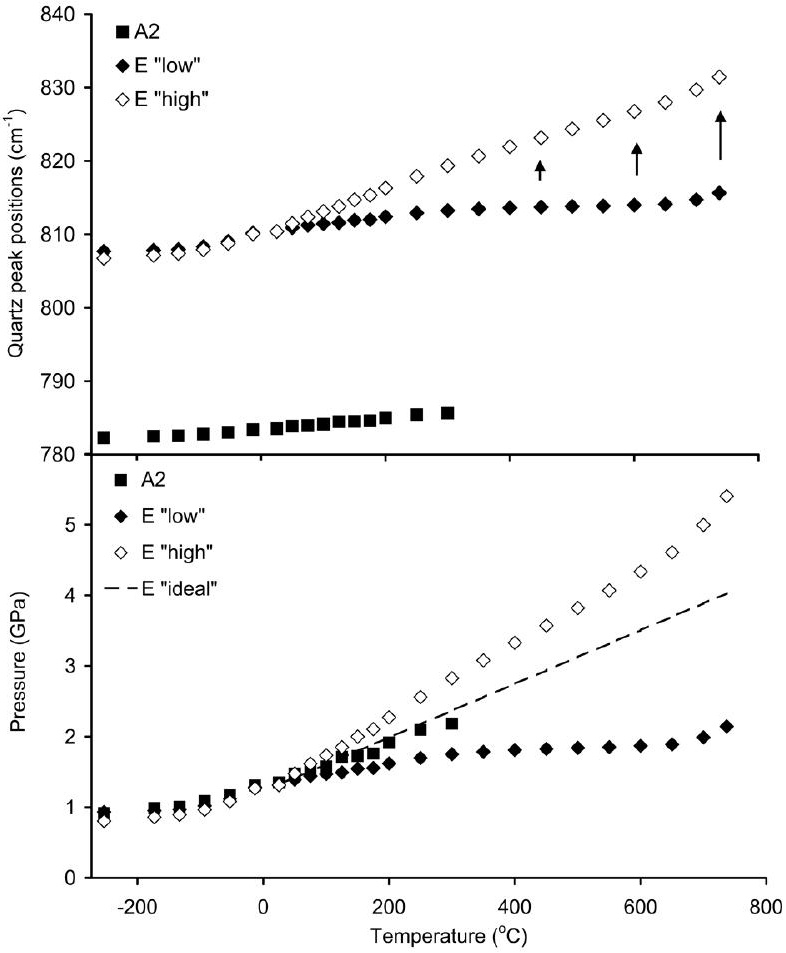




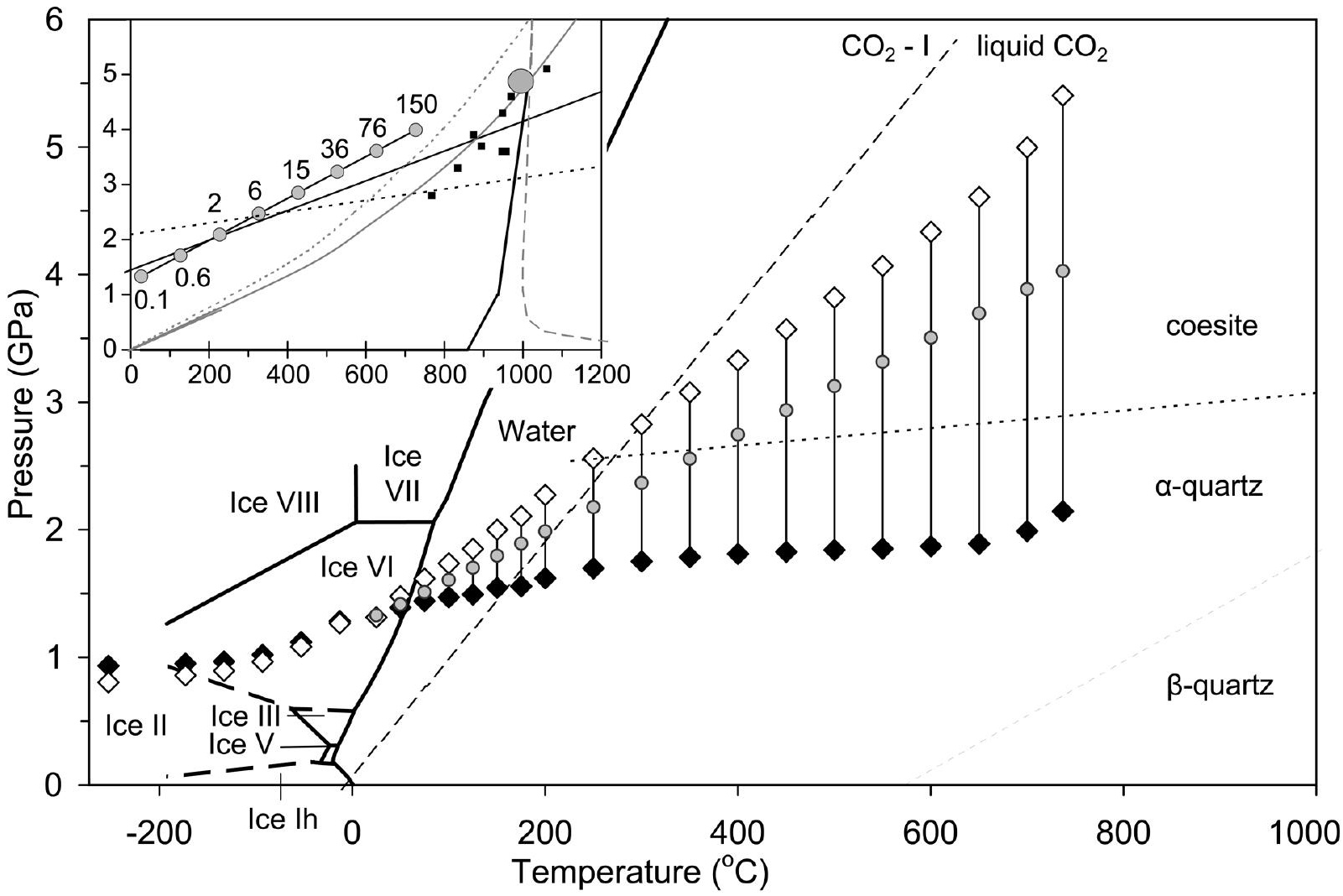

